解 説

\title{
元素機能代替への新たなアプローチ
}

\author{
原田幸明
}

(独)物質・材料研究機構，テ305-0047つくば市千現 1-2-1.

\section{New Approach for the Substitution of Functions Based on Elements}

\author{
Kohmei Halada \\ National Institute for Material Science, 1-2-1 Sengen, Tsukuba 305-0047, Japan.
}

Received December 10, 2008

\section{SYNOPSIS}

A new approach to materials' innovation of substitution of rare elements by common elements is discussed. The importance of the innovation of substitution is insisted from the viewpoint of increasing materials' supply risk. A national project named "Elements Science \& Technology" is mentioned to start efforts to sustainable use of resources. While "reduce", "recycle", "substitution" and "restriction" are keywords in the project, fundamental substitution is expected with great interest. For the fundamental substitution, a new concept named "Lattice Engineering" is introduced. Family concepts of lattice engineering, namely, meta-metallurgy, instructed interatom infrastructure and nano-alchemy are also introduced.

\section{KEY WORDS}

sustainable use of resource, substitution, lattice engineering, instructed inter-atom infrastructure, nano-alchemy

\section{1 はじめに}

開発途上国の経済の拡大や地球温暖化対策などのエコイノ ベーションや情報技術の進展の中で, 資源に対する世界的需 要が拡大し, 資源供給リスクの増大が認識されるようになつ てきている，その解決の方向として, 経済, 外交だけでなく エンジニアリング, 特に材料科学的分野にも強く期待がもた れている，特に希少金属の元素機能の「代替」は，資源問題 を解決していく上での技術サイドに対して抱かれている大き な期待である.この元素機能の代替において注意すべきこと は，新奇の物質 (substance) が創生されてもそれを素材 (Engineering Material)化してはじめて意味を持つことである. その素材化という点で粉末治金技術は大きな可能性を持って いる.ここでは，まず資源リスクについて簡単に触れ，その 材料科学的な解決への取り組みとしての元素戦略を紹介し, その中でも重要な「全面代替」へのアプローチのひとつとして 進めているラティス・エンジニアリング (Lattice Engineering) および類似の概念について述べる.

\section{2 資源リスク}

資源リスクを強めている大きな要因は二つある。一つは，
世界規模での経済の拡大であり, 特にBRICs諸国(ブラジル, ロシア, インド, 中国) と呼ばれる国々の発展や開発途上国 のインフラストラクチャーの整備など従来型の資源需要が急 速に高まっている. Fig.1は, 2008年に筆者らの報告した 2050 年までの金属の累積消費予測である ${ }^{1)}$ 。これは, 日本などの 経済発展指標としての一人当たりの GDP (国内総生産) と一 人当たりの各金属の消費量のパターンを調べ ${ }^{2)}$, BRICs 諸国 が同様の消費パターンで成長していくとして予測したもので ある. 各金属によって消費量が大きく異なるため図はそれぞ れの金属の埋蔵量を 1 としてあらわしてある. 図中の短い横 バーは埋蔵量ベースと呼ばれる数值で, 埋蔵量は経済的成立 性も考慮された可採量であるのに対して, 埋蔵量ベースは, 経済限界下も含めた可採量であり，このラインを超えるとい うことは現在確認された資源だけでは賄えないことになる。 金, 銀, 銅, 鈶, 覀鈶, 錫, アンチモン, インジウムなどが この埋蔵量ベースを超えた需要が予想されている.しかも, これにはIT (情報技術) やエコイノベーションで期待されて いる高機能のレアメタルの需要増はほとんど組み込まれてい ない.

第二の要因として, このITやエコイノベーションに応える 
Several times amount of resources will be raquired by 2050 .

It will be close to the amount of reserve by 2050 :

$\mathrm{Fe}, \mathrm{Mo}, \mathrm{W}, \mathrm{Co}, \mathrm{Pt}, \mathrm{Pd}$

It will require several times amount of reserve by 2050: $\quad \mathrm{Ni}, \mathrm{Mn}, \mathrm{Li}, \mathrm{In}, \mathrm{Ga}$

It will run over the amount of reserve base by 2050: $\quad \mathrm{Cu}, \mathrm{Pb}, \mathrm{Zn}, \mathrm{Au}, \mathrm{Ag}, \mathrm{Sn}$

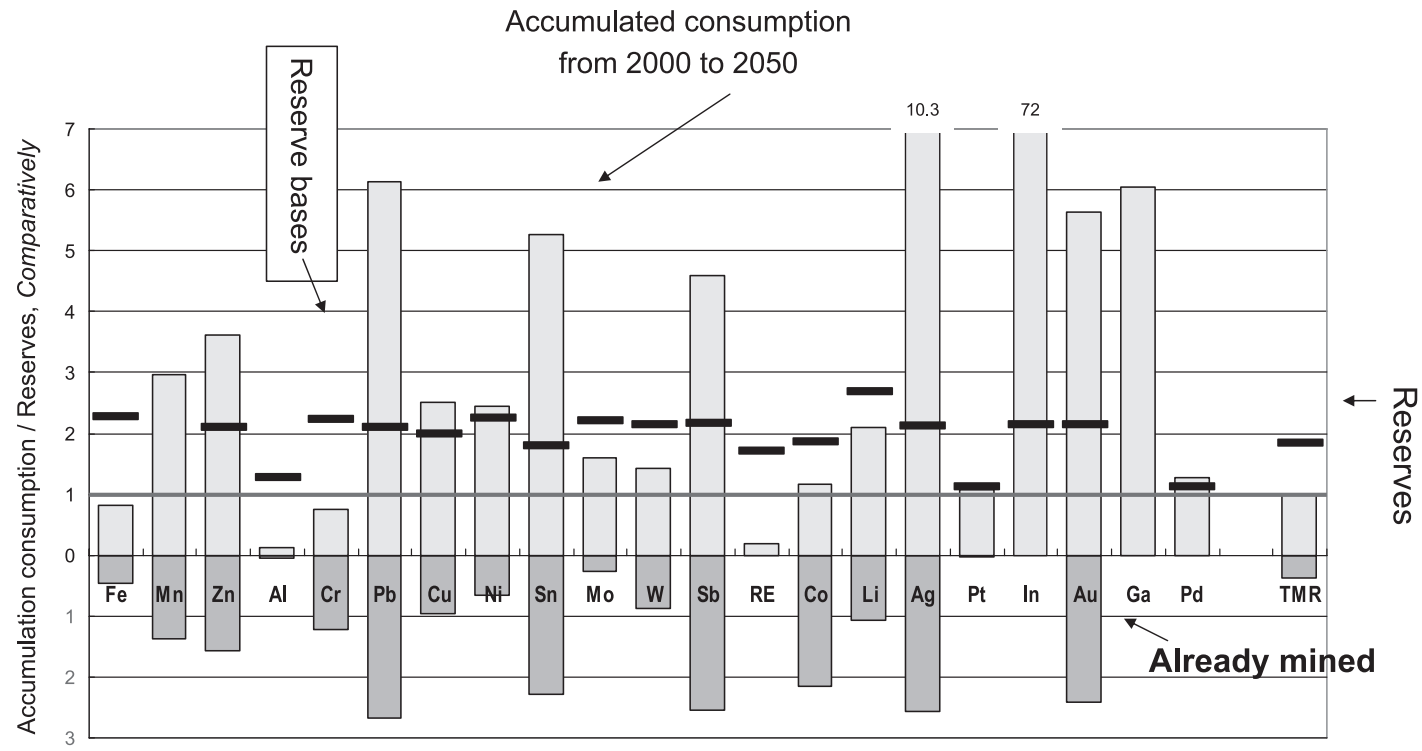

Fig.1 Estimated accumulated consumption of metals up to 2050 comparing existing reserves.

Energy

Generation, conversion, storage
Energy use

Heat actuation, illumination, information
Cleaning

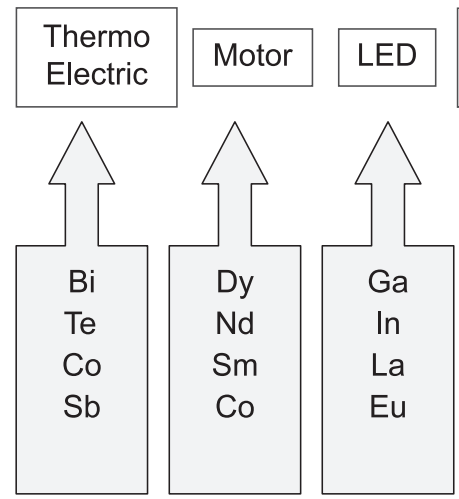

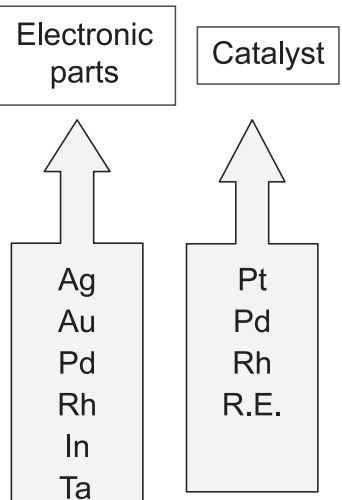

W

$\mathrm{Ni}$

\section{Eco-innovation requires new demand of rare materials.}

Fig.2 Rare metals which will be used more and more in the field of eco-innovation.

ための新規のレアメタル類の需要増大がある. Fig.2に示すも のは, エコイノベーションの中で期待されている新規のレア メタル類である. 電子機器, 磁石, 機能性半導体素子などで の資源供給リスクはより一層大きなものと想定される.
さらに, 資源リスクを考える上で無視できない要因として 地政学的な問題がある.特に希少性の高い金属ほど地球の限 られた部分に偏在しており, 資源ナショナリズム等との関係 で供給が難しくなるケースも十分に配慮しておく必要がある. 


\section{3 持続可能な資源利用の道}

金属など鉱物資源は, 石油など化石燃料とならんで非再生 性資源の一つと言われている.これは, 生物資源とは異なり, 一旦掘削したら同じ場所から再生することはない, また, 資 源の存在場所は地質学的に与えられておりそれを変更するこ とができない，などによるものである．非再生性の資源は基 本的に過去の地質活動の産物であり，そのためいずれは掘り 尽くされ枯渴するものと信じられている. 先述の使用量の增 大の予測からも資源枯渴が目前に迫っているかのような錯覚 も生じている.

しかし, 枯渴とは井戸の水がなくなるようにパタッと供給 が途絶えるということではない. 既存の資源の採取が困難に なって価格の乱高下などでその供給が厳しくなるのに対して 他の資源へと対象が移行するなかで既存資源が使われなく なってくるという状態をその既存資源の枯渴と理解しておく のが良い.そのことを考えると, 資源の持続可能な利用とは, その対象となる資源に対して,

・資源の効率的利用を図ること(減量)

・使用済資源の再生利用を図ること(循環)

とともに,

・資源の探索と見直しによる資源の拡大

・より普遍的な資源の利用 (代替)

の道を追求していくことになる.

そもそも資源問題の根源は, 自然界が準備している資源之 人間経済が利用している資源の間に大きな違いがあることに
ある. Fig.3には上部に各元素の地殻存在度を球の大きさで表 わし，下部は現在の市場規模を示している. FeやAlなどは地 凯存在度も高く市場規模も大きいが，他の多くの金属はこの 間にアンバランスがある.きわめて長期的な展望で言うなら ば，資源の利用を極力地壳存在度の高い資源，いわゆる大地 を構成している成分, たとえば $\mathrm{Si}, \mathrm{Fe}, \mathrm{Al}, \mathrm{Ca}$ などをべースに して求められる特性を発揮していくことが持続可能な資源利 用への展望となる.

もちろん，それはきわめて長期的な目標であり，それに至 るには長い年月がかかるだろうが, 鉱物資源は非再生性の資 源だからといって悲観的になることはなく，長期的目標に到 る科学の役割を認識しておく必要がある. また，もちろんそ れに到るまでに，希少金属資源などもその有用性を活用しつ つ減量, 循環などで資源利用の幅を広げていくことが不可欠 であるとは言うまでもない，そのような長期的展望と，目前 の資源供給リスクに対する問題解決の二つの側面から, 希少 資源・元素戦略は見ていく必要がある.

\section{4 希少金属・元素戦略と代替技術}

希少金属・元素戦略は, 2007 年から経済産業省と文科省が 共同で動かしだした材料研究のプロジェクトである. 経済産 業省は希少金属の中でも緊要性の高い金属をとりあげ具体的 にW, Dy, Inを対象にそれらの減量, 代替を進める課題からス タートした. 一方で文科省は「元素戦略」として全面代替や 大幅な減量化などの長期的な展望を切り開く視点と，それぞ

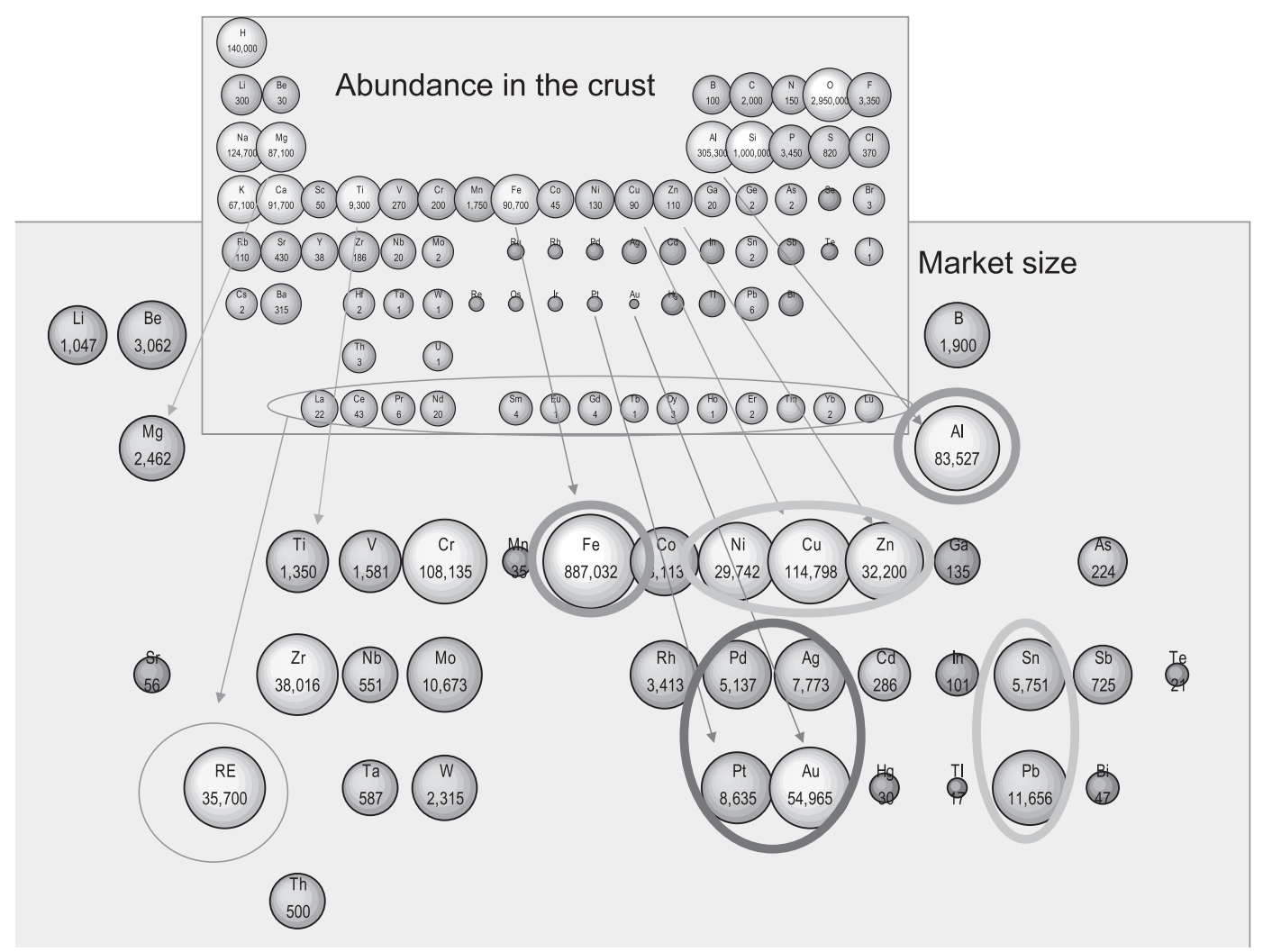

Fig.3 The unbalance of metal usage (market size; bottom) and supplied by nature (abundance in the crust; top). 
れの特徵を活かしながら進めようというものである.

元素戦略は, 当初「減量戦略」「代替戦略」「循環戦略」「規 制戦略」として議論され始めた。これは, 隇量, 循環なご $3 \mathrm{R}$ (Reduce, Reuse, Recycle) に係る部分に，化学物質りスクの側 面も眼を配りながら，「代替」を積極的に組み込んだものであ る. 元素戦略で揭げたられ視点は以下のようなものである.

○元素の持つ特性を深く理解し活用する, 元素多様性の発 掘と物質創造

○物質・材料の特性・機能を決める元素の役割を解明し利用 する観点から「材料研究のパラダイム」を変革し, 新しい 材料の創製につなげる研究

多様な基礎研究を結集し, 希少元素・有害元素の代替技術 等の開発による社会貢献

すなわち, むしろ新しい物質創生の課題として「減量」「代替」 「循環」「規制」を捉えることが期待されている．その様な観 点から, 従来の「代替」に対して元素戦略にあらたに提起さ れたものが「全面代替」である。

\section{5 全面代替の考え方}

全面代替と従来の代替技術の相違は, 目的とする機能の発 現を基本的に異なった構造やメカニズムで行わせるか，同一 のメカニズムの類似物質による置き換えを図るかの違いであ る. たとえば, 従来から試みられているNiフリーのステンレ ス鋼で $\mathrm{Ni}$ の替わりに同様にオーステナイト形成の $\mathrm{Mn}$ を用い オーステナイトの結晶構造の中の置換原子を置きかえるのは 従来型の代替である. Mn は $\mathrm{Ni}$ よりは相対的に豊富であるが これもレアメタルのひとつとして数えられており地政学的な 状況によってはさらなる代替を探さねばならなくなる。 それ に対して, 空気中に普遍的に存在する窒素を格子間に侵入さ せることでオーステナイト相を安定化させる手法は全面代替 に近いものである.さらには，結晶構造の全く異なるフェラ イト系でオーステナイト系と同様の腐食挙動を実現させてい く試みも異なったメカニズムでの機能代替といえる.

全面代替の適例として乾電池中の $\mathrm{Hg}$ の代替開発があげら れる. 乾電池中の $\mathrm{Hg}$ は $\mathrm{Zn}$ 粒間抵抗の低隇之表面での水素過 電圧の制御のために添加されていたものである. 開発の初期 においては, 化学的, 状態図的に類似の $\mathrm{Pb} や \mathrm{~Pb}-\mathrm{In}$ 合金など

\section{Noble functions created by structure control}

- Multi crystal structure: casting, sintering

- Recrystalization control: thermo-mechanical control

- Boundary structure of crystal

Lattice structure on $\longrightarrow$ Electronic state control by

- Interface structure correlation, ordering, arraying

- Two-dimensional structure

- One-dimensional structure

- Nano-dot

Fig.4 A hierarchy of structure control.
が試みられ, 従来型の代替を追求していたが完全代替には至 らなかった.ところが粒間抵抗増加のメカニズムを調べるこ とで, 粒間抵抗は亜銧粒固有の問題ではなく亜鉆粒子中の Fe 不純物が表面に析出するためだとりうことが明らかになった。 これにより, $\mathrm{Fe}$ の不純物濃度の低い亜鈆粒子を製造する技術 を開発することで，水銀の代替を超えて水銀ゼロ，鉛，イン ジウム等の代替もゼロの乾電池とすることができている.

最近の例としては, 東工大の細野によるC12A7 と呼ばれる $(\mathrm{CaO})_{12}\left(\mathrm{Al}_{2} \mathrm{O}_{3}\right)_{7}$ による透光性と導電性の共存材料の開発があ げられる ${ }^{3)}$ ここれは, 絶縁体であるC12A7にケージ(籠) 構造 をとらせそこに電子が励起しやすい状態を現出することで導 電性を確保したものである.これは透光と合わせて透明電極 としての可能性があり，長期的にITO (インジウム錫酸化物) の代替として, $\mathrm{ZnO}$ や $\mathrm{TiO}$ などの類似系とは全く異なった材 料開発の余地があることを示している.

このような全面代替を進めていくには，代替すべき機能を 絞り込み，その機能の出現要素を明確にし，その出現要素を いかなる同等性をもって代替させていくのということになる. その際, 注目すべき機能がいかなる物質の状態から得られて いるのかについて把握することが肝要である. たとえば, 物 質の性質はFig.4のように異なった幾重かの階層性の中で得ら れている. その中で, Fig.5に示すようないかなる同等性を保 持することが必要かということになる. かってはこの部分は 研究者の経験的演繹や独自の発想に依存する傾向が強かった が, 現在では計算材料学が大きく進歩し，特に電子軌道の設 計では第一原理からの計算が可能となってきている.

さらに，そこで現出されるべき現象を材料として具体的に 作りこむ技術が必要となる.このプロセシングでは材料の階 層性制御が問題となってくる. 先述の電子軌道の設計では基 本的にナノの構造が対象とされるが, そのナノ構造をヒトが ハンドリング可能な素材レベルの制御と結びつけることが求 められる. その際, ナノ構造を単純なバルク系で制御するこ とは難しいケースが多く, 界面や粒子複合系の利用が重要に なる. 材料系のいくつかの学会が集まって議論した際にもそ のようなインターフェイス制御が成分制御とともに元素戦略

\section{Approachs for radical substitution}

Substitutions of atomic elements by reference function

- Case1 size equivalency of atoms or ions

- Case2 equivalency of electron state

- Case3 equivalency of transporter

- Case4 equivalency of localized potential

- Case5 equivalency of interface structure

- Case 6 emerging of hidden function by removal of disturbance

- Case7 alternative function for reference application

Fig.5 Points aimed at substitution the function. 
の鍵となるという見解が多く, Fig.6はそのような階層性と物 質への作りこみという観点からまとめられたものである.

このように, 元素全面代替戦略は, ナノ領域の機能発現か ら材料としての作り込まで材料化学および材料科学を結集し た取り組みとして実現できる.

\section{6 ラティス・エンジニアリング(Lattice Engineering)} のアプローチ

このような全面代替の基礎となるのは機能発現である. 特 に近年注目されている機能の多くは，電子，ホール，フォト ン, フォノン, スピン等の授受や相互作用によっている.こ れらは一般に物質中の電子軌道を基礎にその遷移, 分裂など によりもたらされるエネルギーレベルの変化を外界との相互 作用として取り出すことにより目的機能を発現させている. 従来の物質選択は, この目的機能に合致する電子構造をとり やすい物質を見出し，他の機能的特性と妥協させながら材料 化していくことであった．その際，元素やその化合物はぺロ ブスカイトなりウルツァイトなり自然界で得られやすい構造 が前提とされ，ドーパントの添加などでその基本構造に若干 の変更を加えることで微妙な電子構造の制御を行い最適化を 進めてきた。すなわち，ある機能目的のための物質系をあら
かじめ限定するために物性科学的知見が用いられ，そこでふ るい分けられた, 言うならばエリート物質に対して微調整を 施していることに相当する.

ここで, そのエリート物質を主体として考えるのではなく, そこに現出している電子構造に着目し, 他の基底的な状態は 無視して物質探索の幅を広げるという手法が近年とられるよ うになってきている.これは, 主として計算科学の進歩によ り, 電子やそのバンドギャップの状態の予測が可能となった ことを背景にしている. 光触媒の開発においてYeのとった手 法 $^{4)}$ はその典型例として挙げられる. Yeは光触媒の可能性を $\mathrm{TiO}_{2}$ 系に限定することなく, 各種金属酸化物のバンドギャッ プ計算を行い, さらにその酸化物系に加えて他元素を挿入す ることによりバンドギャップの変化を計算し光触媒として適 する物質系の組み合わせを得ている.こうして開発したもの には, $\mathrm{Ta}$ 酸化物系や $\mathrm{Nb}$ 酸化物系のみならず, $\mathrm{sp}$ 混成軌道が バンドギャップとなる $\mathrm{Ba}_{2} \mathrm{In}_{2} \mathrm{O}_{5}$ 系も光触媒として有効なこと が見出されている.

Yeの例は直接遷移型のバンドギャップ設計の典型例とも受 け取ることができ物質創生よりも物質探索の成功例とみるこ ともできる. 計算科学はこのバンドギャップ設計やプラズモ ン, フォノン等の量子状態, ホール等の移動ポテンシャルな

\section{Essentials of Elenements' Science and Technology}

Practical, General

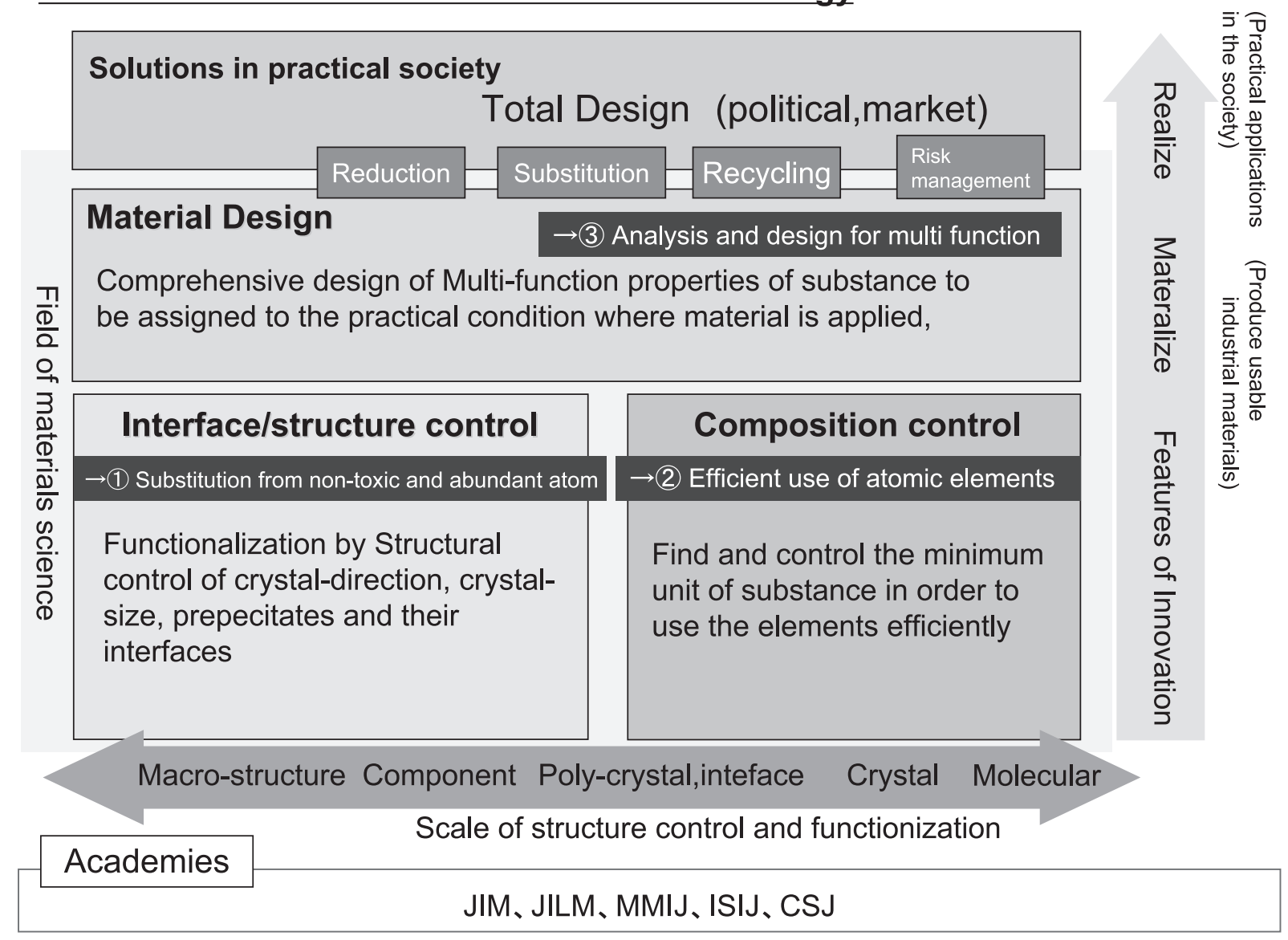

Fig.6 Expected Principle research elements in the research project of "Elements Science \& Technology". 
ぞを，その結晶構造の安定性とあわせて設計することができ る段階にきている.これを全面代替にむけて物質探索から物 質創生へとすすめていく必要がある. 物質探索の場合にはこ れらの設計の基整単位となるユニットは元素の組み合わせと その安定性で与えられるといってよい，それに対して物質創 生の場合は, ユニット自体を設計もしくは異相界面などを活 用して局所的に実現していくことまでも対象となる.

先述の細野の場合のケージ構造もそのような取り組みとし て理解できる. 篠原は $12 \mathrm{~A} 7$ の表面に $\mathrm{CaO}$ 膜が形成されそこ に拡散された酸素により電子が励起しやすい状態が現出して いることに注目し，界面との相互作用を生かしてユニット内 部の電子状態を制御し導電性という特性を獲得した例として 指摘している ${ }^{5}$.このような発想を拡張すれば界面ならずと も結晶格子中に複数の機能をもつユニットを設定しそのそれ ぞれを制御することで, 複数の特性を獲得させることも可能 となる.たとえば古くから熱電材料として知られる $\mathrm{FeSi}$ は一 見複雑な結晶構造であるが角度を変えてみればFig.7のような 二次元ユニットの組み合わせとみることができる．このユ ニットの中でキャリア伝導に寄与しているSi層ユニットに対 してドーピングやユニット境界条件の変化などを与えること で，優れたキャリア伝導性させる設計と他ユニットを活用し た構造的強度をもたらすことができる5
このように現在期待されている多くの現象が格子レベルの サイズの原子間構造によって電子状態を制御することによっ て得られている. 現在はこの原子間構造は無機物では格子, 有機では分子鎖の上の状態として認識されているが，これを 層状，籠状，ディストーションなどの構造をもった機能ユ ニットとして積極的に制御することによってこの格子に配置 された原子の自由度を広げていくことが期待できる.これを 格子サイズの制御ということでラティス・エンジニアリング と呼ぶことができる，その概念を記したものが Fig.8である. これまで, 個々の特性追及はそれぞれの分野で特有の手法で 追求されてきたが,このように共通の手法の異なる適用系で あるとして横断的に考えれることでその可能性が大きくなる と期待できる.

\section{Meta-Metallurgy としての物質設計技術}

このラティス・エンジニアリングは，格子サイズというこ とでラティスという表現を用いたが,これは金属や化合物の 結晶のような長期的周期構造のみを意識しているわけではな い. 周期性はなくとも原子の配置と相互関係で電子状態を制 御して機能を取り出している凝縮系全体についても言えるこ とである. 最近開発がすすんでいる有機半導体などの有機機 能物質もその対象であり,むしろこれまで合金や化合物半導

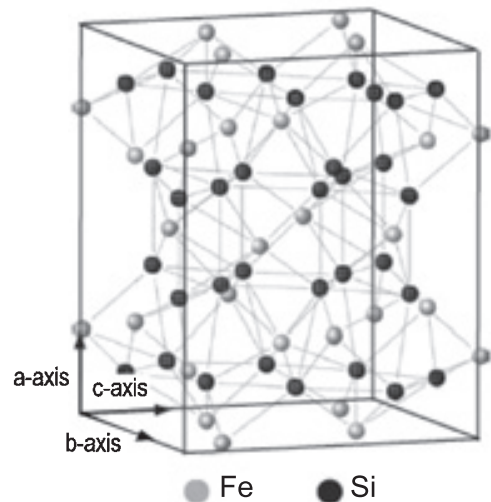

a) Crystal structure of $\beta-\mathrm{FeSi}_{2}$

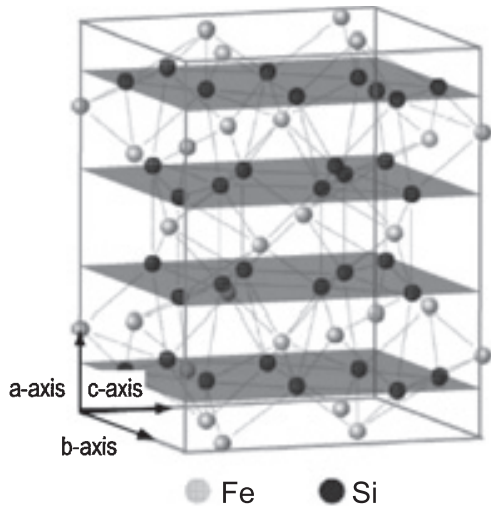

b) Crystal structure of $\beta-\mathrm{FeSi}_{2}$ as structural units

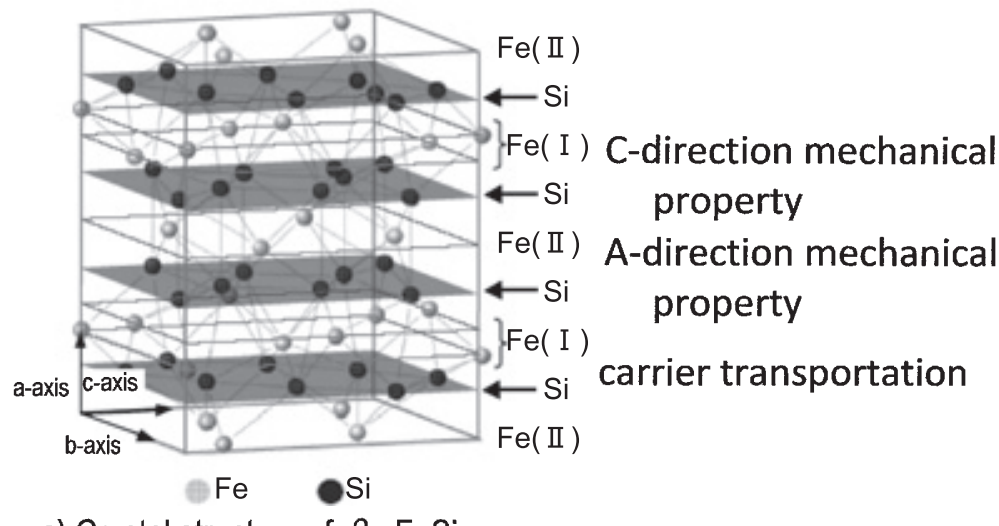

c) Crystal structure of $\beta-\mathrm{FeSi}_{2}$ as functional units

Fig.7 Unit of inter-atom infrastructure of FeSi. 


\section{Lattice Engineering (= atomic arrangement)}

\section{Considering function units not as the kind of elements but its arrangement and consequently generated electron status.}

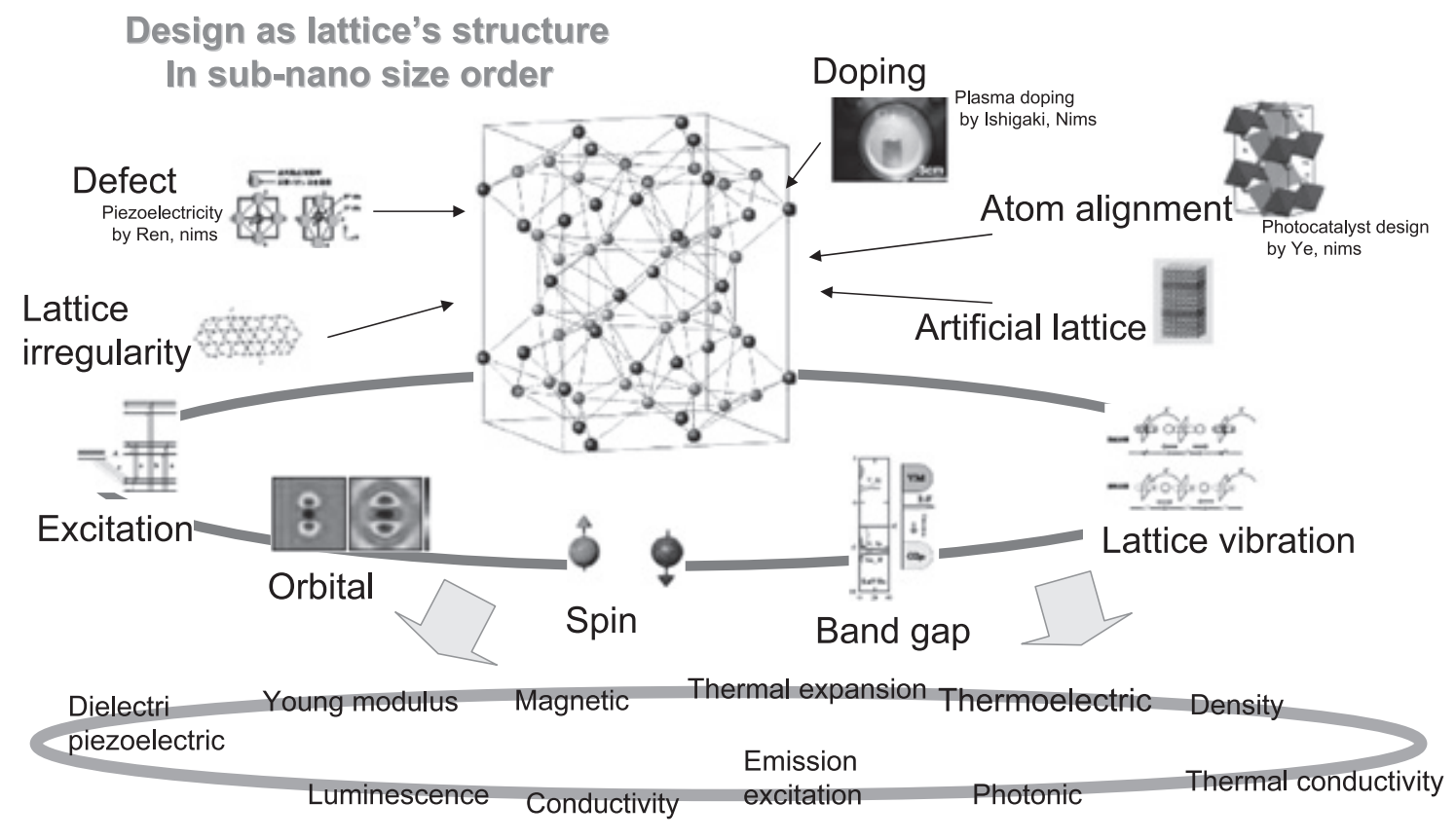

To enrich of the Possibility of Element Selection from common resources

Fig.8 Concept of lattice engineering.

体の設計に用いられた手法を有機系に持ち込む上で有効な手 法論として発展させうる. また有機結晶や高分子鎖相互作用 などにおいてもこのラティス・エンジニアリングの発想を持 ち込むことであらたな観点が切り開かれることも期待される. もちろんそのフィードバックとして従来の結晶構造にもとづ く電子状態設計に対しても, 有機系でできる低密度キャリア, 長い緩和時間などが接合部の漏れの制御などに生かされる可 能性もある。

さらに, 近年物性科学においては多秩序系が注目されてい る.これは従来理解されていたようなひとつの低エネルギー 状態に一つの安定状態が存在しているのではなく, 多数の状 態が存在可能であり，その微妙な摇らぎの変化で別種の特異 な現象が現出するというものであり, 新超伝導材料の探索な ごにおいて大きな期待が寄せられている.この多秩序系の現 出に対しても，理論の段階から物質化していく上でこれらの 制御・設計技術が貢献し，従来の元素の組み合わせの範囲を 超えた新たな系で特殊な現象を実現していく可能性がある.

このように，ラティス・エンジニアリングは基本的に半導 体工学を含む冶金工学的発想の物性物理から出発するアプ ローチであるが, その物性物理的本質から有機, 無機を超えて 共通の議論可能な物質制御手法として, 発展させることがで きる.いうならば凝縮系における原子間の相互構造の構築を ベースにした機能設計としてinstructed inter-atom infrastructure とでも呼ぶべきとらえ方.さらには結晶制御の学としてのメ夕 ラジーをより本源的に踏み込むものとして, メタ・メタラジー (Meta-Metallurgy)とでも呼ぶべき存在になりうると期待される.

これを支える背景として, 近年のナノテクノロジーと計算 科学の前進がある.ナノテクノロジーは, 物質の状態を原子 配列レベルで観察することを可能とした. Fig.9は, 鋼の中で 析出効果を起こす析出物の観察例である ${ }^{6}$. 従来化合物とし てしか把握できなかったこれらの析出物が格子状態として観 察されることにより, 図中のマーキング部分のキンクが機能 しているというような強化のメカニズムの議論も深まると共 に，その要素である元素にこだわらない設計の可能性も大き くなってきている.

また, 計算科学の進歩は大きく, $10 \times 10 \times 10$ 原子のサイズ ならば第一原理計算が可能な段階まできている。これらの基 礎技術をもとに, これまでの物性科学の知識を横断的に結び つけるならば，メタ・メタラジーとしてのアプローチの仕方 が自ずと明らかになってくることが期待される。

\section{8 おわりに}

持続可能な資源利用の方向を意識した, 元素全面代替戦略 として, ラティス・エンジニアリングという視点を論じた. こ 


\section{TiC nano-carbide in steel}
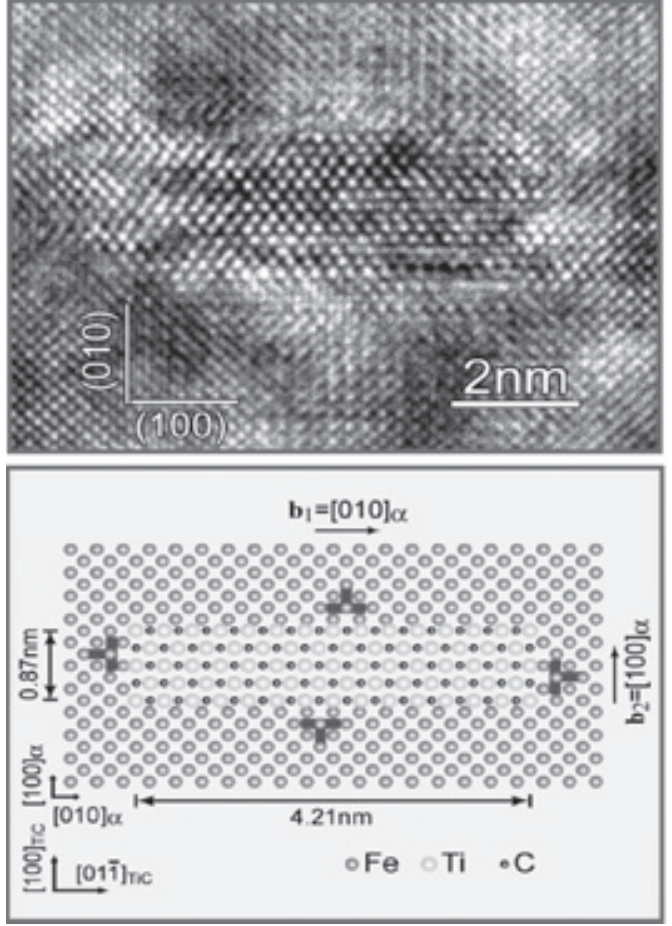

The inverse FFT image is rotated for $45 \mathrm{deg}$.

Fig.9 An example of nano-scale observation of atomic structure of precipitation in steel.

のような視点は現在さまざまなところで問題意識がもたれて いる. 本稿においてもメタ・メタラジーやInstructed Inter-atom structureなどという造語を多用したのもこれらの問題意識と の接点を求めたいためである. 元素戦略の全面代替の素材開 発が従来の代替材料の枠を超えて, 新しい物質創生へと結び つくことが期待される.これこそ,ナノテクノロジーが材料 技術を変革し, 従来の元素にこだわつた材料設計から脱却し ていく,いうならば, 鍊金術(alchemy)が否定され元素に基づ く科学が構築されたのに対して, その新しい段階としてナ ノ・アルケミー (nano-alchemy) とでも呼ぶべきものが構築さ れていくのではないだろうか.

\section{文献}

1) K. Halada, M. Shimada, and K. Ijima: "Forecasting of Consumption of Metals up to 2050", Materials Transactions,
49(2008)402-410.

2) K. Halada, M. Shimada, and K. Ijima: "Decoupling Status of Metal Consumption from Economic Growth", Materials Transactions, 49(2008)411-418.

3) H. Hosono and M. Hirano: "Toumei Sankabutsu Kinouzairyou to sono ouyou", CMC press, Tokyo, (2006).

4) D. Wang, Z. Zou, and J. Ye: Photocatalytic "Water Splitting with the $\mathrm{Cr}$-doped Oxide Semiconductor", Chemistry of Materials, 17(2005)3255-3261.

5) Y. Shinohara: "Genso senryaku no tameno metaragii no fukkatsu", Genso Senryaku Outlook, NIMS, (2007).

6) F-G. Wei, T. Hara, and K. Tsuzaki: "High-resolution transmission electron microscopy study of crystallography and morphology of TiC precipitates in tempered steel", Phil. Mag., 84(2004) 1735-1751. 